\title{
Supplementary Information for \\ Printed Electrode for Measuring Phosphate in Environmental Water
}

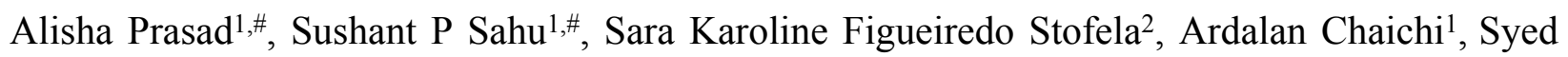
Mohammad Abid Hasan ${ }^{1}$, Wokil Bam³, Kanchan Maiti³, Kevin M McPeak², Gang Logan Liu, Manas Ranjan Gartia ${ }^{1, *}$

${ }^{1}$ Department of Mechanical and Industrial Engineering, Louisiana State University, Baton Rouge, Louisiana, USA 70803

${ }^{2}$ Department of Chemical Engineering, Louisiana State University, Baton Rouge, Louisiana, USA 70803

${ }^{3}$ Department of Oceanography and Coastal Sciences, Louisiana State University, Baton Rouge, Louisiana, USA 70803

${ }^{4}$ Department of Electrical and Computer Engineering, University of Illinois, Urbana-Champaign, Illinois, USA 61801

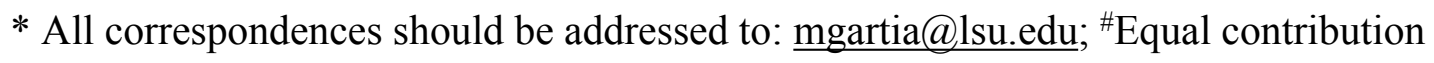

Table of Content

Figure S1 Image of electrochemical apparatus setup for Three-electrode........................ S-3

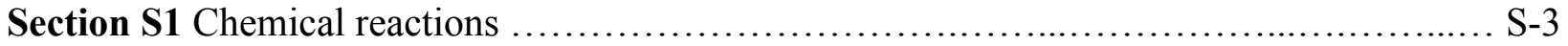

Figure S2 Current-time response profile of the phosphate sensor ........................... S-4

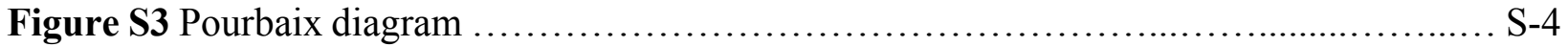

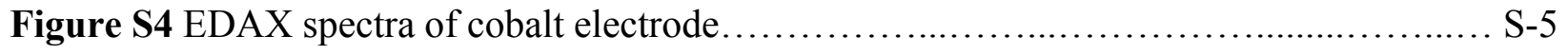

Figure S5 Effect of $\mathrm{pH}$ on the current response of the sensor ............................ S-6

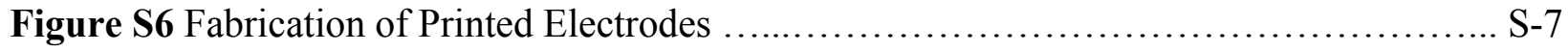

Figure S7 Step by step fabrication process of Printed Electrodes .......................... S-7 
Figure S8 Phosphate sensing using the printed electrodes.

Figure S9 Evaluation of the effect of dissolved oxygen on the phosphate sensor ........S-8

Table S1 Concentration of Phosphate in Mississippi water by Electrochemical method...........S-9

Table S2 Comparison of electrochemical and colorimetric sensor data ................... -9

Table S3 Concentration of Phosphate in Mississippi water by Spectrophotometric method.....S-10

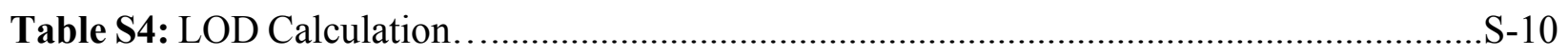

Table S5: Literature on sensing performance of phosphate sensor.................................S-11

Table S6: Evaluation of cobalt sensor response in presence of Dissolved Oxygen ...............S-11

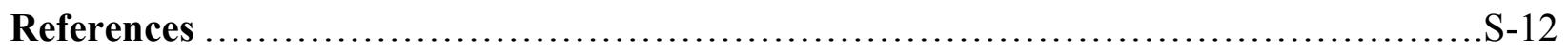




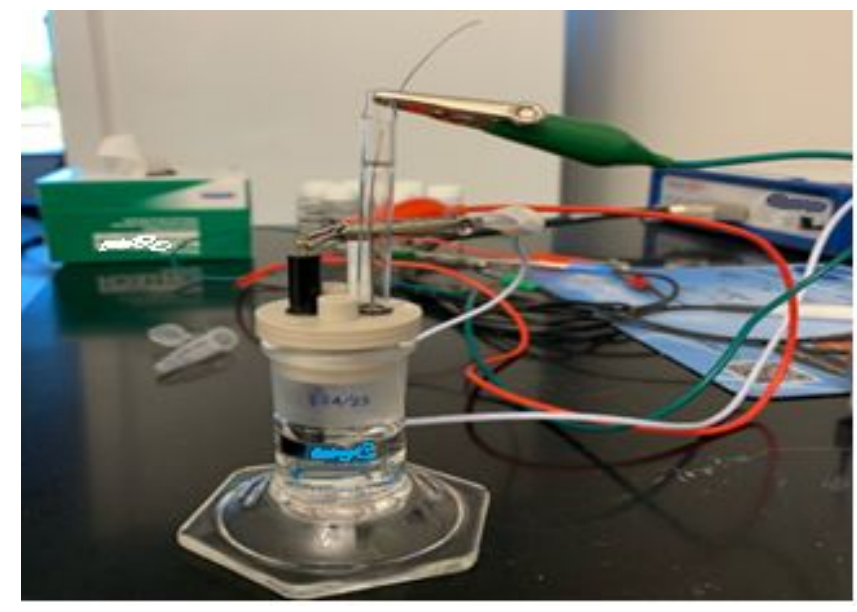

Figure S1. Electrochemical apparatus setup. Green: Working Electrode; Red: Counter Electrode; White: Reference Electrode

Section. S1 Chemical reactions

$$
\begin{aligned}
2 \mathrm{Co}+2 \mathrm{H}_{2} \mathrm{O} & \Leftrightarrow 2 \mathrm{CoO}+4 \mathrm{H}^{+}+4 \mathrm{e}^{-} \\
\mathrm{O}_{2}+4 \mathrm{H}^{+}+4 \mathrm{e}^{-} & \Leftrightarrow 2 \mathrm{H}_{2} \mathrm{O} \ldots \ldots \ldots \ldots \ldots \ldots \ldots \ldots \ldots \ldots \ldots \ldots \ldots \ldots
\end{aligned}
$$

$3 \mathrm{CoO}+2 \mathrm{PO}_{4}{ }^{3-}+3 \mathrm{H}_{2} \mathrm{O} \Leftrightarrow \mathrm{Co}_{3}\left(\mathrm{PO}_{4}\right)_{2}+6 \mathrm{OH}^{-}$at $\mathrm{pH} 11.0$

The chemical reactions from equation (1) to (6) are explained below:

1. Reduction (cathode): The phosphate ions associate at the Co electrode surface, generating $\mathrm{Co}^{2+}$ to $\mathrm{Co}^{0}$ (cathodic peak) redox couple.

2. Oxidation (anode): The $\mathrm{Co}^{2+} / \mathrm{Co}^{0}$ redox couple influences the electrode surface and leads to formation of $\mathrm{Co}_{3}\left(\mathrm{PO}_{4}\right)_{2}$ (anodic peak).

3. Acidic state (pH:4.0): Corresponds to dihydrogen phosphate $\left(\mathrm{H}_{2} \mathrm{PO}_{4}{ }^{-}\right)$(Ref. 1).

4. Neutral state (pH:8.0): Corresponds to hydrogen phosphate $\left(\mathrm{HPO}_{4}{ }^{2-}\right)$ (Ref. 2).

5. Basic state ( $\mathrm{pH}: 11.0)$ : Corresponds to phosphate $\left(\mathrm{PO}_{4}{ }^{3-}\right)$ ions (Ref. 2). 
a

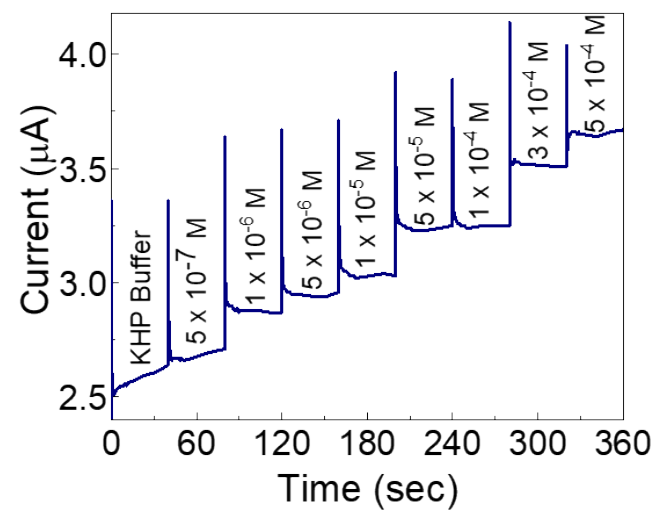

b

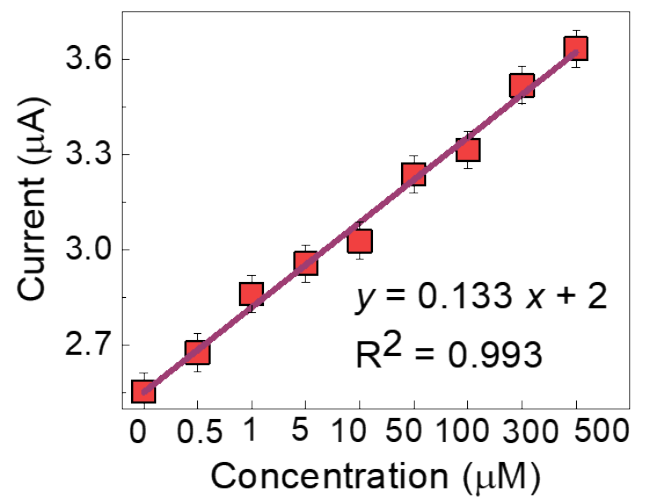

Figure S2. Current-time response profile of the phosphate sensor (a) Chronoamperograms showing the phosphate sensor response at different phosphate concentrations. (b) Phosphate sensor calibration curve showing linear range of detection from $10^{-7} \mathrm{M}$ to $10^{-4} \mathrm{M}$ with bulk cobalt wire.

a

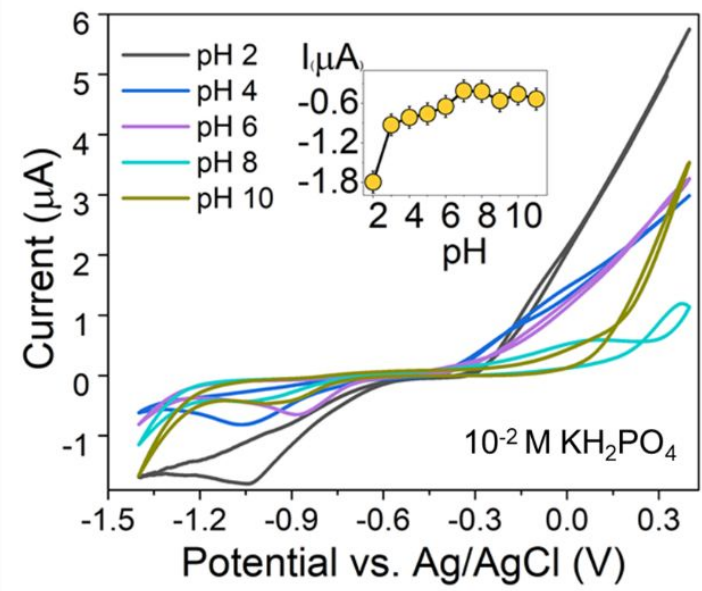

b

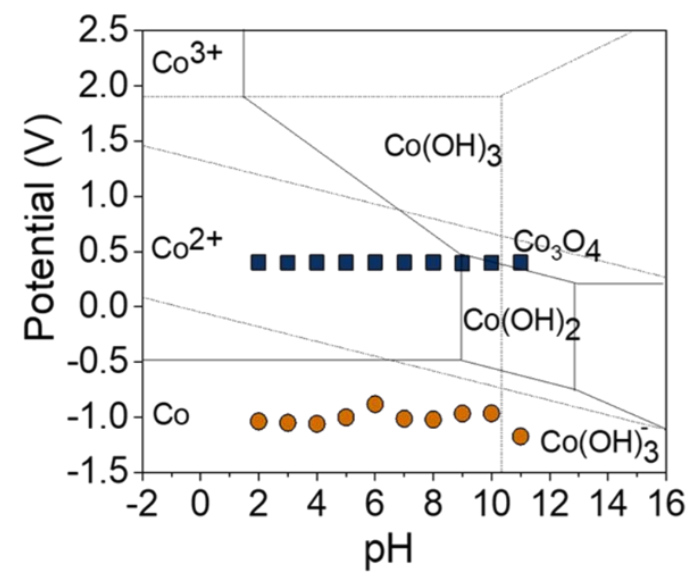

Figure S3. (a) Effect of $\mathrm{pH}$ on the CV. (b) Pourbaix diagram of cobalt sensor showing thermodynamic $\mathrm{pH} /$ potential characteristics in the $\mathrm{pH}$ range of 2 to 11 . The pre-catalytic redox features evident in the CVs (Figure S3a) is denoted by symbol $\mathbf{a}$ at the anode and $\bullet$ at the cathode, respectively. 
a
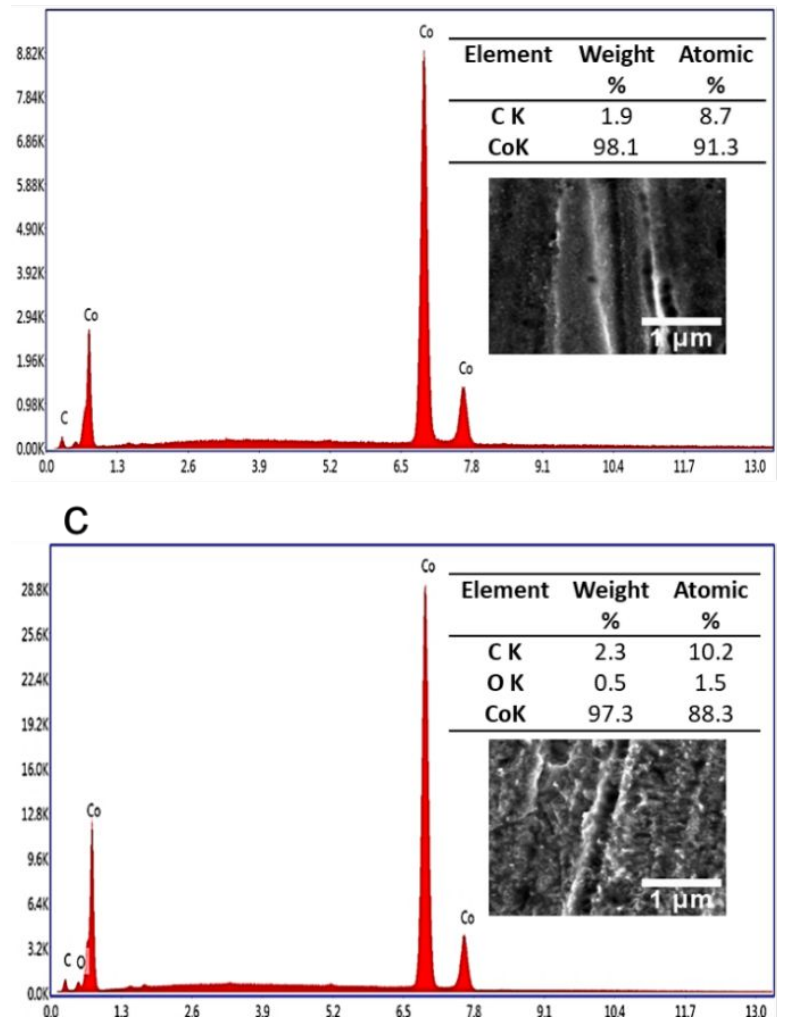

b

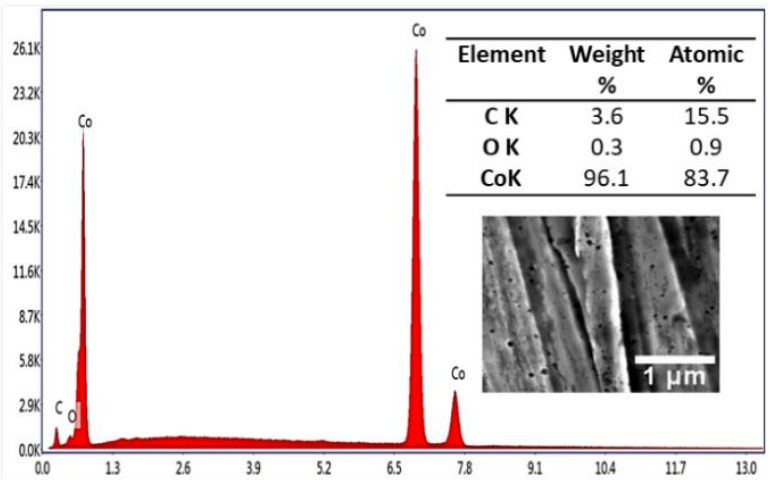

d

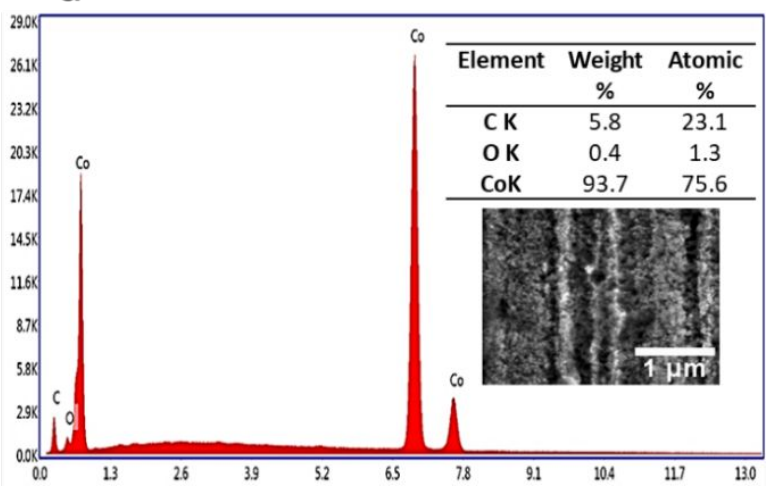

Figure S4. EDAX spectra of cobalt electrode (a) Bare Cobalt wire, (b) in KHP Buffer (10 cycles $\mathrm{CV})$, (c) in KHP Buffer $+\mathrm{KH}_{2} \mathrm{PO}_{4}\left(10\right.$ cycles CV), and (d) in KHP Buffer $+\mathrm{KH}_{2} \mathrm{PO}_{4}(20$ cycles $\mathrm{CV}$ ). From the EDAX spectra of the cobalt electrode presented in Figure $\mathbf{S 4}$ under various test conditions a decrease in the EDAX weight \% across test solutions (a-d) from $98.1 \%$ to $93.7 \%$ for element $\mathrm{Co}$ in the $\mathrm{K}$-shell was observed which is due to the oxidation of cobalt $\left(\mathrm{Co}^{0}\right.$ to $\left.\mathrm{Co}^{2+}\right)$ as explained in the XPS studies. 

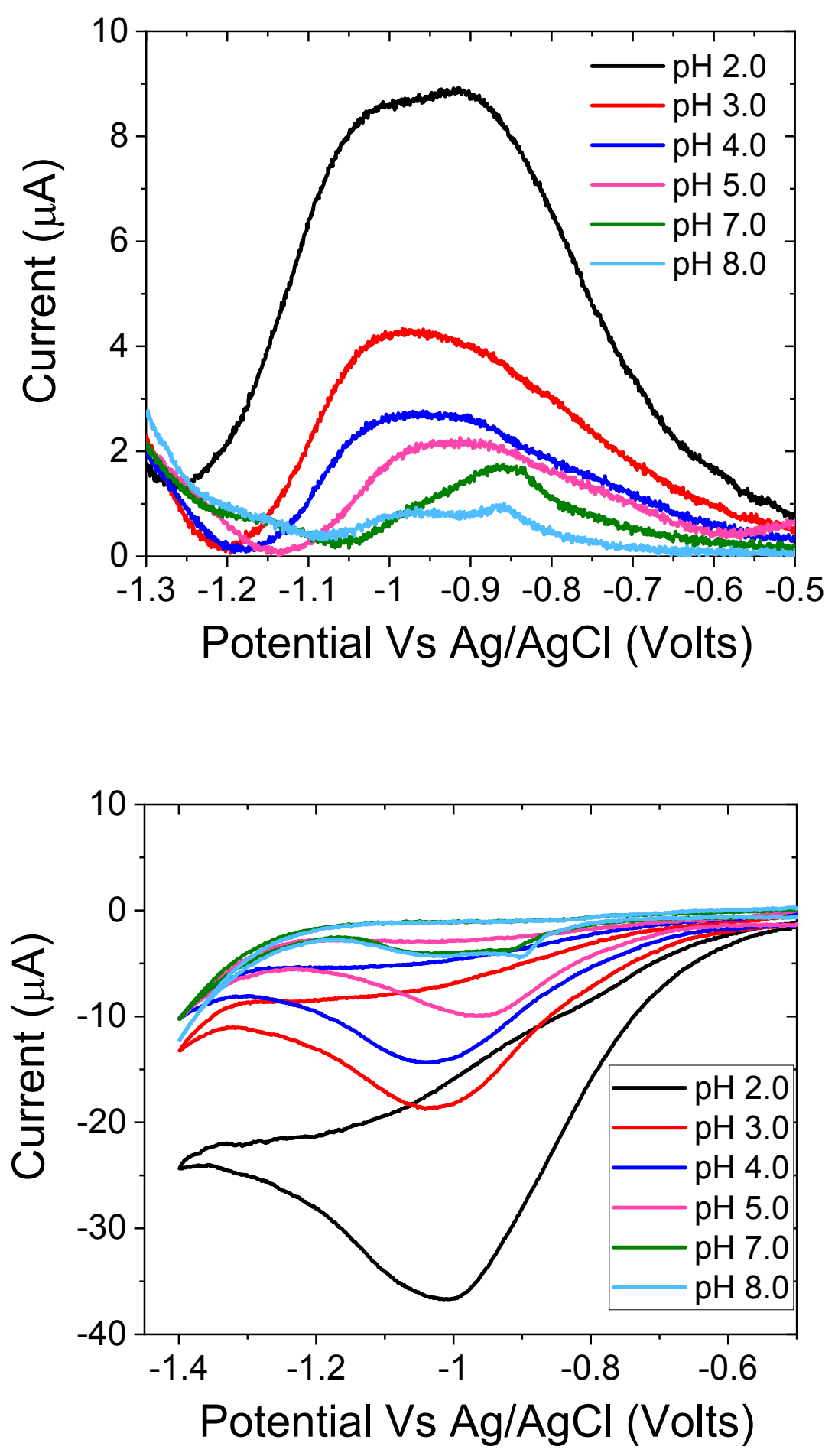

Figure S5. (Top) Square wave pulsed voltammograms showing the characteristic cathodic current response of sensor, and (Bottom) Cyclic voltammograms showing the characteristic cathodic current response of sensor measured for $100 \mu \mathrm{M}$ phosphate in the $\mathrm{pH}$ range 2 to 8 . 


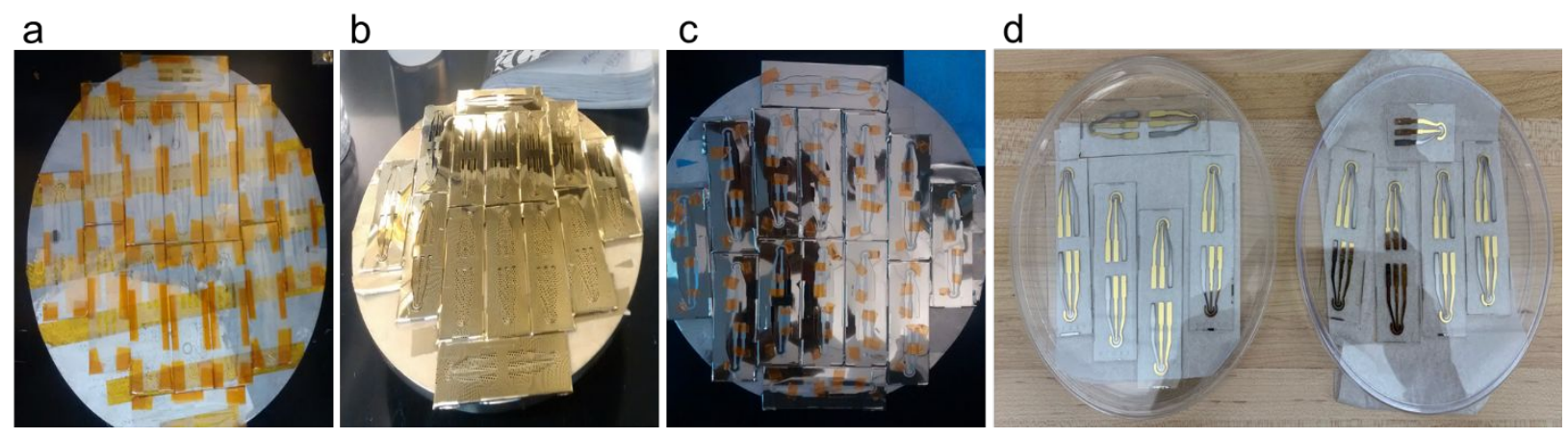

Figure S6. Fabrication of Printed Electrodes. (a) Loading Mylar pieces taped on glass slide for metal deposition (b) After deposition of Gold layer (c) After deposition of Cobalt layer (d) Mass Production of Printed electrodes
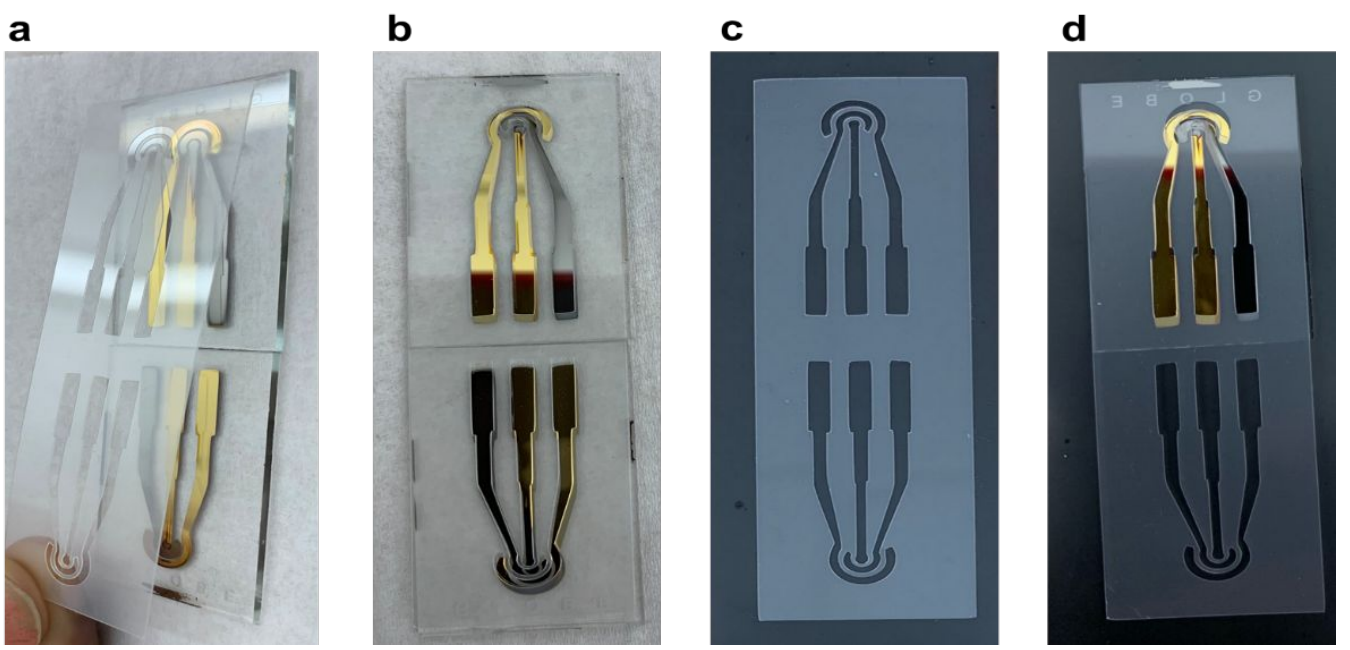

Figure S7. Step-by-step process of making glass printed electrodes. (a) Masking using Mylar sheets (b) Final output after metal deposition (c-d) In black background. 


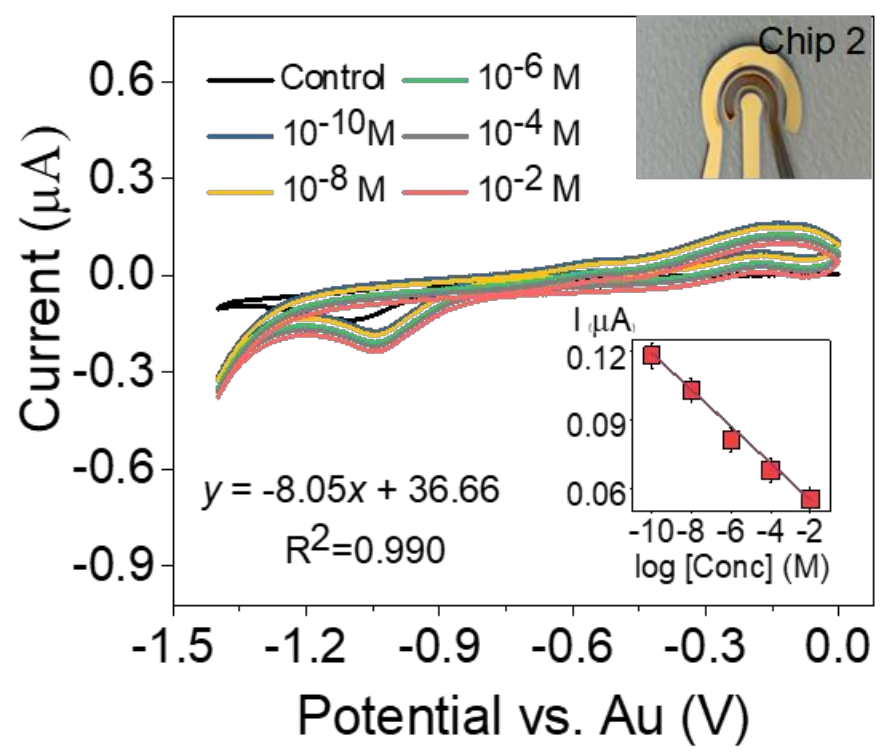

Figure S8. Phosphate sensing using the printed electrodes. Cyclic voltammograms of Co-metal as working electrode with Au-metal as reference electrode and counter electrode in $25 \mathrm{mM} \mathrm{KHP}$ buffer and $1 \mathrm{mM} \mathrm{KCl}$ with $\mathrm{KH}_{2} \mathrm{PO}_{4}$ in the concentration range of $10^{-10} \mathrm{M}$ to $10^{-2} \mathrm{M}$ with a scan rate of $50 \mathrm{mV} \mathrm{s}^{-1}$. Inset: Phosphate sensor calibration curve showing linear range of detection in $10^{-10}$ $\mathrm{M}$ to $10^{-2} \mathrm{M}$. Note: The current signal obtained from the buffer was subtracted from all sample peak currents.
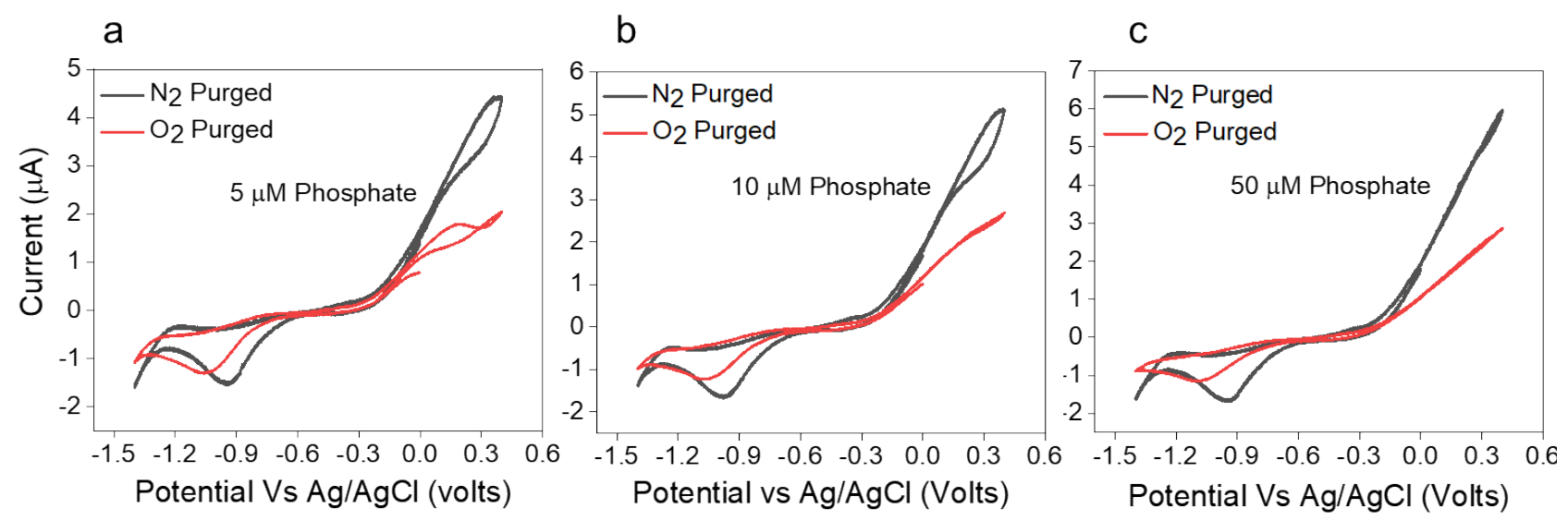

Figure S9. Evaluation of the effect of dissolved oxygen on the phosphate sensor. (a) $5 \mu \mathrm{M}$ (b) 10 $\mu \mathrm{M}$ (c) $50 \mu \mathrm{M}$ of orthophosphate. 
Table S1: Concentration of Phosphate in Mississippi water samples by Electrochemical method

\begin{tabular}{|c|c|c|c|c|c|c|}
\hline DATE & \multicolumn{2}{|c|}{$\begin{array}{c}\text { Phosphate Concentration } \\
(\boldsymbol{\mu M})\end{array}$} & $\begin{array}{c}\text { Mean } \\
(\boldsymbol{\mu M})\end{array}$ & $\begin{array}{c}\text { Mean } \\
(\mathbf{m g} / \mathbf{L})\end{array}$ & $\begin{array}{c}\text { Standard } \\
\text { Deviation }\end{array}$ & $\begin{array}{c}\text { Coefficient } \\
\text { of Variation } \\
(\mathbf{C V} \%)\end{array}$ \\
\hline 1 & 5.66 & 5.4 & 5.53 & 0.536 & 0.18 & 3.3 \\
\hline 2 & 4.27 & 5.1 & 4.69 & 0.454 & 0.59 & 12.5 \\
\hline 3 & 4.51 & 4.57 & 4.54 & 0.440 & 0.04 & 0.9 \\
\hline 4 & 4.77 & 4.25 & 4.51 & 0.437 & 0.37 & 8.1 \\
\hline 5 & 4.34 & 3.9 & 4.12 & 0.399 & 0.31 & 7.5 \\
\hline 6 & 1.65 & 1.8 & 1.73 & 0.167 & 0.11 & 6.1 \\
\hline 7 & 4.94 & 5.77 & 5.36 & 0.519 & 0.59 & 10.9 \\
\hline 8 & 4.83 & 4.49 & 4.66 & 0.452 & 0.24 & 5.2 \\
\hline 9 & 3.93 & 3.52 & 3.73 & 0.361 & 0.29 & 7.8 \\
\hline 10 & 2.94 & 2.38 & 2.66 & 0.258 & 0.40 & 14.9 \\
\hline 11 & 3.01 & 3.34 & 3.18 & 0.308 & 0.23 & 7.4 \\
\hline 12 & 1.01 & 1.2 & 1.11 & 0.107 & 0.13 & 12.2 \\
\hline 13 & 2.64 & 2.31 & 2.48 & 0.240 & 0.23 & 9.4 \\
\hline 14 & 1.37 & 1.21 & 1.29 & 0.125 & 0.11 & 8.8 \\
\hline
\end{tabular}

Table S2: Comparison of electrochemical and colorimetric sensor data

\begin{tabular}{|c|c|c|r|r|}
\hline Days & Electrochemical & Colorimetric & Difference & \multicolumn{2}{l|}{$\begin{array}{l}\text { Difference } \\
\text { (Abs) }\end{array}$} \\
\hline 1 & 5.53 & 4.74 & 0.79 & 0.79 \\
\hline 2 & 4.69 & 4.76 & -0.07 & 0.07 \\
\hline 3 & 4.54 & 4.3 & 0.24 & 0.24 \\
\hline 4 & 4.51 & 3.55 & 0.96 & 0.96 \\
\hline 5 & 4.12 & 3.42 & 0.7 & 0.7 \\
\hline 6 & 1.73 & 1.72 & 0.01 & 0.01 \\
\hline 7 & 5.36 & 4.24 & 1.12 & 1.12 \\
\hline 8 & 4.66 & 3.67 & 0.99 & 0.99 \\
\hline 9 & 3.73 & 3.57 & 0.16 & 0.16 \\
\hline 10 & 2.66 & 3.68 & -1.02 & 1.02 \\
\hline 11 & 3.18 & 2.36 & 0.82 & 0.82 \\
\hline 12 & 1.11 & 1.17 & -0.06 & 0.06 \\
\hline 13 & 2.48 & 2.2 & 0.28 & 0.28 \\
\hline 14 & 1.29 & 1.68 & -0.39 & 0.39 \\
\hline
\end{tabular}


Table S3: Concentration of Phosphate in Mississippi water samples by Spectrophotometric method

\begin{tabular}{cc}
\hline DATE & Phosphate $(\boldsymbol{\mu M})$ \\
\hline Day 1 & 4.74 \\
\hline Day 2 & 4.76 \\
\hline Day 3 & 4.3 \\
\hline Day 4 & 3.55 \\
\hline Day 5 & 3.42 \\
\hline Day 6 & 1.72 \\
\hline Day 7 & 4.24 \\
\hline Day 8 & 3.67 \\
\hline Day 9 & 3.57 \\
\hline Day 10 & 3.68 \\
\hline Day 11 & 2.36 \\
\hline Day 12 & 1.17 \\
\hline Day 13 & 2.20 \\
\hline Day 14 & 1.68 \\
\hline
\end{tabular}

Table S4: LOD Calculation

\begin{tabular}{ccc}
\hline Iteration & \multicolumn{2}{c}{ Cyclic Voltammetry Buffer Current } \\
\hline & Bulk (mA) & Printed Chip (mA) \\
\hline $\mathbf{1}$ & -0.001307441 & -0.000115847 \\
\hline $\mathbf{2}$ & -0.001307032 & -0.000115689 \\
\hline $\mathbf{3}$ & -0.001307437 & -0.000116001 \\
\hline STDEV & $2.35 \mathrm{E}-07$ & $1.56351 \mathrm{E}-07$ \\
\hline LOD & $7.05 \mathrm{E}-07$ & $4.69052 \mathrm{E}-07$ \\
\hline
\end{tabular}


Table S5: Analytical parameters and comparison of potentiometric sensing performance of phosphate sensor with previous published reports

\begin{tabular}{|c|c|c|c|c|c|}
\hline $\begin{array}{l}\text { Sl. } \\
\text { No. }\end{array}$ & $\begin{array}{l}\text { Active material (Ion } \\
\text { Selective Electrode) }\end{array}$ & $\begin{array}{c}\text { Dynamic } \\
\text { linear range }\end{array}$ & Detection limit & References & Year \\
\hline 1 & $\begin{array}{c}\text { Glass Printed Cobalt } \\
\text { electrode }\end{array}$ & $10^{-10}$ to $10^{-2} \mathrm{M}$ & $10^{-7} \mathrm{M}$ & \multicolumn{2}{|c|}{ Present Work } \\
\hline 2 & $\begin{array}{c}\text { Screen Printed } \\
\text { electrode modified with } \\
\text { carbon black } \\
\text { nanoparticles }\end{array}$ & $\begin{array}{l}10 \times 10^{-6} \text { to } \\
80 \times 10^{-6} \mathrm{M}\end{array}$ & $6 \times 10^{-6} \mathrm{M}$ & 3 & 2015 \\
\hline 3 & Cobalt microelectrode & $10^{-5}$ to $10^{-1} \mathrm{M}$ & $10^{-5.1} \mathrm{M}$ & 4 & 2009 \\
\hline 4 & $\begin{array}{l}\text { Planar Cobalt } \\
\text { microelectrode }\end{array}$ & $\begin{array}{l}5 \times 10^{-5} \text { to } \\
5 \times 10^{-2} \mathrm{M}\end{array}$ & $10^{-5} \mathrm{M}$ & 5 & 2006 \\
\hline 5 & Cobalt wire & $10^{-4}$ to $10^{-2} \mathrm{M}$ & Not mentioned & 2 & 1996 \\
\hline
\end{tabular}

Table S6: Evaluation of electrochemical phosphate sensor response in presence of Dissolved Oxygen

\begin{tabular}{|c|c|c|c|}
\hline Phosphate Concentration $(\mu \mathrm{M})$ & 5 & 10 & 50 \\
\hline I $\left(\mathrm{N}_{2}\right)(\mathrm{mA})(\mathrm{At}-1.05 \mathrm{~V})$ & -0.00153 & -0.00164 & -0.00166 \\
\hline $\mathrm{I}\left(\mathrm{O}_{2}\right)(\mathrm{mA})(\mathrm{At}-1.05 \mathrm{~V})$ & -0.00129 & -0.00121 & -0.00116 \\
\hline $\begin{array}{c}\text { Percentage Difference }(\%) \\
{\left[\left(\mathrm{N}_{2}-\mathrm{O}_{2}\right) / \mathrm{N}_{2} * 100\right]}\end{array}$ & 15.68 & 26.21 & 30.12 \\
\hline $\begin{array}{c}\text { Correlation Coefficient (\%) } \\
{\left[\mathrm{I}_{(\mathrm{N} 2 \text { - O2) }} / \mathrm{DO} \mathrm{O}_{(\mathrm{N} 2 \text { - O2) }} * 100\right]}\end{array}$ & 0.004 & 0.007 & 0.008 \\
\hline
\end{tabular}




\section{References}

(1) Xiao, D.; Yuan, H.-Y.; Li, J.; Yu, R.-Q., Surface-modified cobalt-based sensor as a phosphatesensitive electrode. Anal. Chem. 1995, 67 (2), 288-291.

(2) Meruva, R. K.; Meyerhoff, M. E., Mixed potential response mechanism of cobalt electrodes toward inorganic phosphate. Anal. Chem. 1996, 68 (13), 2022-2026.

(3) Talarico, D.; Cinti, S.; Arduini, F.; Amine, A.; Moscone, D.; Palleschi, G., Phosphate detection through a cost-effective carbon black nanoparticle-modified screen-printed electrode embedded in a continuous flow system. Environ. Sci. Technol. 2015, 49 (13), 79347939.

(4) Lee, W. H.; Seo, Y.; Bishop, P. L., Characteristics of a cobalt-based phosphate microelectrode for in situ monitoring of phosphate and its biological application. Sens. Actuators B: Chem. 2009, 137 (1), 121-128.

(5) Zou, Z.; Han, J.; Jang, A.; Bishop, P. L.; Ahn, C. H., A disposable on-chip phosphate sensor with planar cobalt microelectrodes on polymer substrate. Biosens. Bioelectron. 2007, 22 (910), 1902-1907. 